\title{
Modern Methods for Cost Management in Construction Enterprises
}

\author{
Peter Mesároš, Tomáš Mandičák, Jozef Selín \\ Technical University of Košice \\ Civil Engineering Faculty, Institute of Construction Technology and Management \\ e-mail: peter.mesaros@tuke.sk, tomas.mandicak@tuke.sk, jozef.selin@tuke.sk
}

\begin{abstract}
Cost management should be seen as an essential function of enterprises which perform their activities in current market environment. One of the main factors affecting the level of achieved profit and favourable market position is cost structure. The company's ability to obtain necessary and reliable information on their own cost, subsequent processing and effective cost management is crucial for achieving success. This study focuses on cost management and the use of modern methods of cost management in construction enterprises. The aim of this paper is to identify approaches to cost management in Slovak construction enterprises, based on own empirical research.
\end{abstract}

Key words: costs, cost management, information base, construction enterprises

\section{Introduction}

Cost planning is a natural and effective activity of each business entity enhancing the chance for analysing the possible risks and create adequate rules and knowledge of their behavior. It is an important tool for cost management.

Objectively compiled costs plan is an important condition for cost management and effective performance of the company. This is true because the cost is the important indicator of the quality of the company's work, because they reflect the procurement, production and sales activities of the company.

Managers should know how and where costs are incurred, they should manage the activity, or processes and know how their decisions affect the cost structure. Therefore, an administrative cost information is required at the right time. 


\section{Traditional versus modern cost management}

The basic costs of the business is the production and implementation of products and services. When defining reasons to costs, we distinguish two main groups of costs in terms of shortterm management [1].

- unit costs, which are controlled primarily by the line output,

- overhead costs, which are managed primarily for divisions.

The basic tool of cost management are especially preliminary calculations. In terms of functions to perform calculations for cost management, different types of calculations and the corresponding cost calculating methods are used.

The new trend is currently searching and creating standard models of governance and sustainable decision-making in cost management [2]. Standardization of management can be implemented in any business. This approach will help us develop more effective procedures in satisfying customer needs. "However, there should be a uniform standard of governance and decision-making, it would essentially fold competitive struggle." Modern management concepts are models that track the essential areas of enterprise and thus set priorities for decision making. Those models, while based on common elements:

- Processes and correct view of them is an important part of successful management (Process Management).

- Customer orientation and to meet their needs is an essential element for management and decision-making (Management by the Customer Quality).

- Measurement processes and their continuous evaluation of financial and non-financial terms is essential flexibility, competitiveness and the firm's survival.

The placing of modern management concepts into practice requires the use of a supporting measurement and evaluation methods [3].

Process management is becoming a condition for understanding the wishes and expectations of the customer. The world moves towards globalization, as well as management discipline towards integration. Process management can be applied in various ways. Pressure on the customer's company is also visible in the development of relatively discrete management disciplines such as quality management, cost management and cost controlling. These hitherto independent disciplines are now integrated system in which the tracking process transparent prerequisite knowledge of the company. 


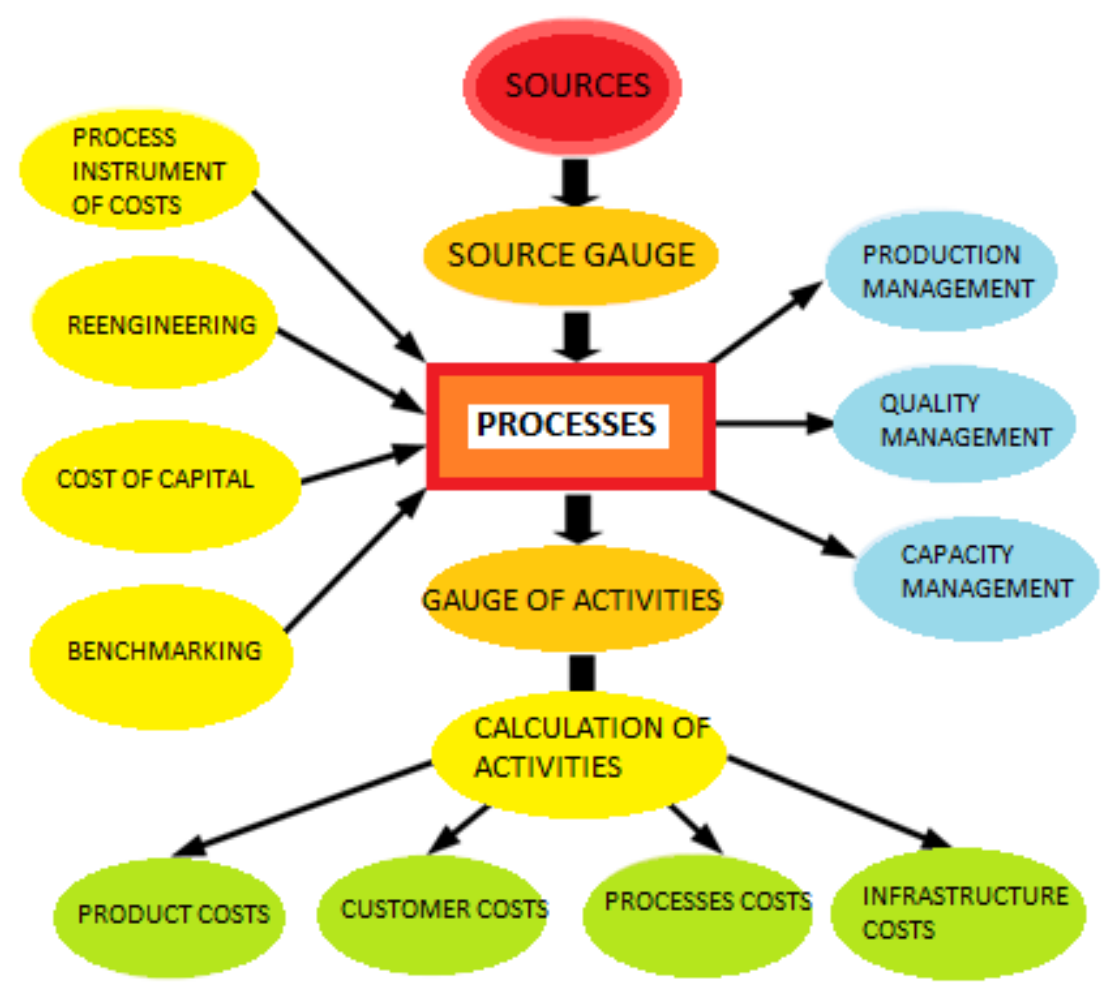

Figure 1: Process approach in managing costs

\section{Process approach of cost management by the ABC method}

International indication of this method is the $\mathrm{ABC}[5,6]$ and this abbreviation is based on the English name of the method - Activity Based Costing. In German literature, this method occurs under the name - Method of calculation process. To simplify the marketing concept costing under sub-activities, we will use the acronym ABC method.

How activities are normally defined by work processes and sub-processes [7,8]. Adding the direct costs shall be made in the same way as traditional methods of calculation.

It follows that the basic principle $\mathrm{ABC}$ method is to assign resources consumed to activities, grouping activities into activities and then assign activities to cost objects (products, services). This principle can be expressed also as follows: at the beginning of our efforts is a customer who consumes our performance, processes and performance consume these internal processes consume resources, the use of which results in a cost $[3,4,5]$.

\section{Research material and methods}

Managers have a direct and significant impact on costs and profit, thereby affecting the competitiveness of the company and the company's ability to achieve long-term goals. 
The main objective of the study is to analyse the current situation in the area of cost management of construction enterprises and identify the cost management approaches in Slovak construction companies.

For the analysis of the current state of the use of information on costs and of cost management in SMEs Eastern Slovakia, the structured questionnaire was selected as an appropriate method for data collection. The questionnaire survey was chosen also because all the studies carried out in different countries in the field of management accounting and of cost management used a structured questionnaire as a method for obtaining information.

The questionnaire survey had the following objective: Identify the extent to which firms use different methods of cost management process and find out the importance of cost management as part of management.

\subsection{Research sample and data processing}

Questionnaire survey was conducted from September 2013 to July 2014. A total of 60 businesses were interviewed, of which 41 questionnaires were returned complete. The return of questionnaires represented $68 \%$. This sample corresponds to the Slovak market construction companies, therefore, can be considered as sufficiently research results and can be used for general conclusions.

The sample consisted of 41 companies. Classification of the enterprises was addressed to the breakdown according to the recommendation of the European Commission 2003/361/ EC. Subsequently, both the sample consists of:

- $51 \%$ small businesses - enterprises employing an interval 10-49,

- $39 \%$ medium-sized enterprises - enterprises employing at intervals of 50 to 249,

- $10 \%$ large enterprises - enterprises employing more than 250 .

After collecting the questionnaires, the results were analyzed and evaluated by means of statistical software STATISTICA and Microsoft Excel. To view the results were used selected types of graphs. For the evaluation questionnaires were chosen statistical methods Chi-square goodness of fit test and ANOVA analysis of variance.

\section{Research results}

In the questionnaire investigation, we determined how businesses use construction cost controlling module, which must be appropriately linked with the enterprise information system. Continuous control of the planned values against actual values is in fact in good time can identify weaknesses in the process of cost management in company. Cost controlling is one of the most developed areas of controlling. There currently are hidden factors present success as cost controlling the highest rate contributes to the effective management and this is where there is the profit. Of course, all this is true if the company has a long correct orientation and trying to have only the right thing to do right cost controlling. This module is used in $36.5 \%$ of companies. In view of size of business, cost controlling is a part of information system in six small companies, five medium and four large enterprises. Statistical 
testing confirmed a significant relationship between firm size and the use of cost controlling only for medium-sized enterprises $(\mathrm{F}$-ratio $=2.775701$, p-value $=0.039414)$. In view of venture capital origin was not confirmed statistically significant relationship, but for companies with domestic capital are already the F-ratio $=2.34816$ and $\mathrm{p}$-value $=0.078737$ close to the critical values.

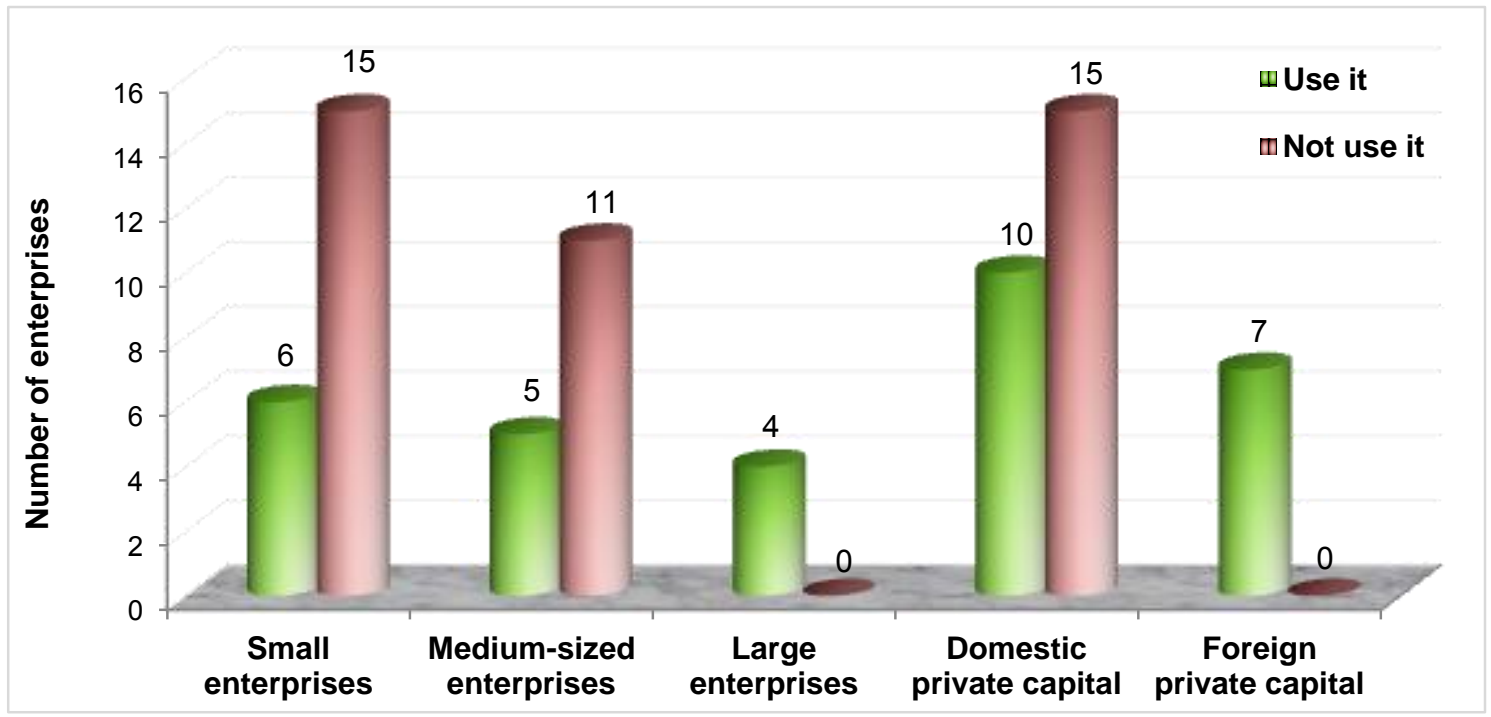

Figure 2: Use of the cost controlling module in the enterprise information system

Further investigation of the issue is related to the intensity of the enterprise cost management - cost controlling (Fig. 3). We see that the data are sufficiently utilized only for large (80\%) and small $(69 \%)$ of enterprises, medium-sized only moderately (52\%). In terms of the type of capital are seen increases the available (Fig. 34), in the case of foreign (85\%) as compared to the average in the case of Slovak capital (59\%). An important element of corporate controlling is controlling costs. Cost controlling is primarily focused on cost management company and thus also naturally yields. It focuses on planning with a view to achieving the objectives in the future. Here are the current factors for success as cost controlling the highest rate contributes to the effective management and this is where there is the profit. Of course, all this applies when an enterprise has a long correct orientation.

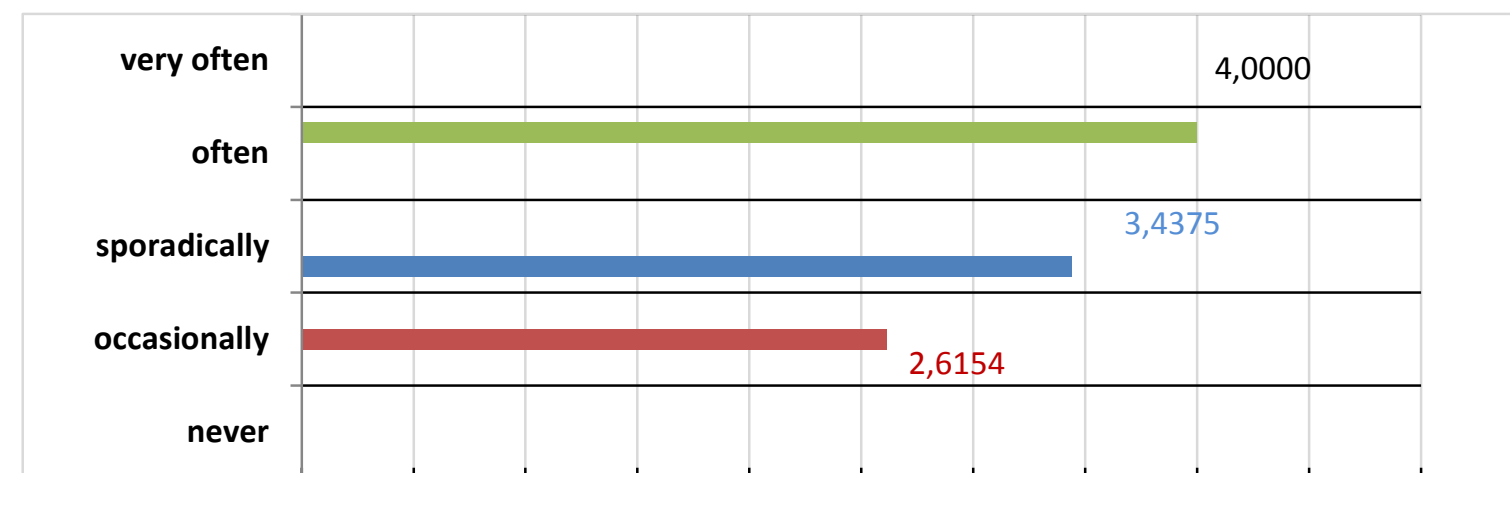

Figure 3: The use of the tool - cost controlling (size of business) 


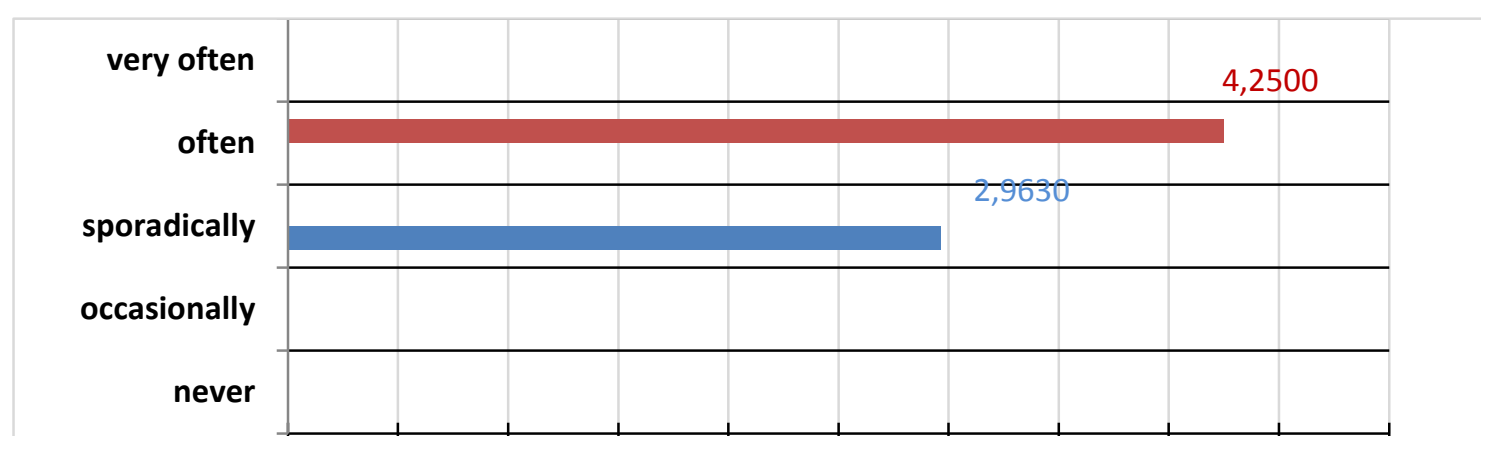

Figure 4: The use of the tool - cost controlling (type of capital)

\subsection{The use of cost data for management decisions}

The first examined the question relates to the use of cost data in managerial decision making. Of FIG. 21 clearly shows that in all enterprises is the matter strongly preferred. In the case of large enterprises even at $100 \%$, but also medium in size, respectively small businesses indicate $97 \%$, respectively $90 \%$ usefulness of the data. In terms of the type of capital is also evident by strong usability (Fig. 5), but with a slight difference in favour of foreign (97\%) compared Slovak (84\%).

It is important to use cost information in a systematic analysis of costs and method of management. Managers should use all available information and decide how to set up and manage effective cost reduction programs that have long-lasting results. Quality management and management decisions at all levels of governance have a significant impact on the viability of enterprise. The fact that managers do not respond continuously to changes in the business environment often leads to reduced termination of business activities.

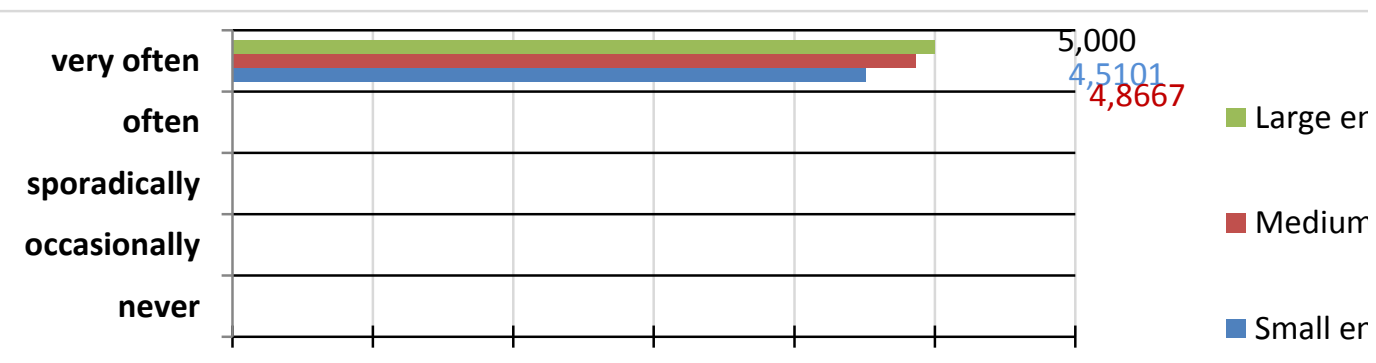

Figure 5: The use of cost data to management decisions (size of business)

Upon further investigation, we determined the use of new tools for managing costs. The need to develop traditional methods of calculations is an integral part of the development of cost management.

Statistical testing confirmed a significant relationship between company size categories and studied both in general (F-ratio $=7.834486249$, p-value $=3.16802 \mathrm{E}-09)$ and also in the case of medium-sized enterprises $($ F-ratio $=2.821665$, p-value $=0.016535)$. and small $($ F-ratio $=$ 4.365567 , p-value $=0.000219$ ). Statistical testing confirmed a significant relationship even if 
firms with Slovak capital $($ F-ratio $=6.567083$, p-value $=2.05-07)$ as well as enterprises with a positive result $(\mathrm{F}-$ ratio $=6.824859, \mathrm{p}$-value $=9.4 \mathrm{E}-08)$.

\subsection{The use of $\mathrm{ABC}$ methods to control costs}

Question 1: I do not know this tool.

In that issue, we investigated the response of construction enterprises to use of cost management by the method ABC. For the first type of answer - I do not know this instrument in favour 16 of 41 businesses, representing 39\% of all enterprises, eight firms (50\%) from the group of medium-sized businesses as well as eight groups of small businesses (38\%).

For large enterprises such alternative has been rejected by all respondents. In terms of type of capital for this type of response decision (41\%) compared with the Slovak enterprises (29\%) with foreign.

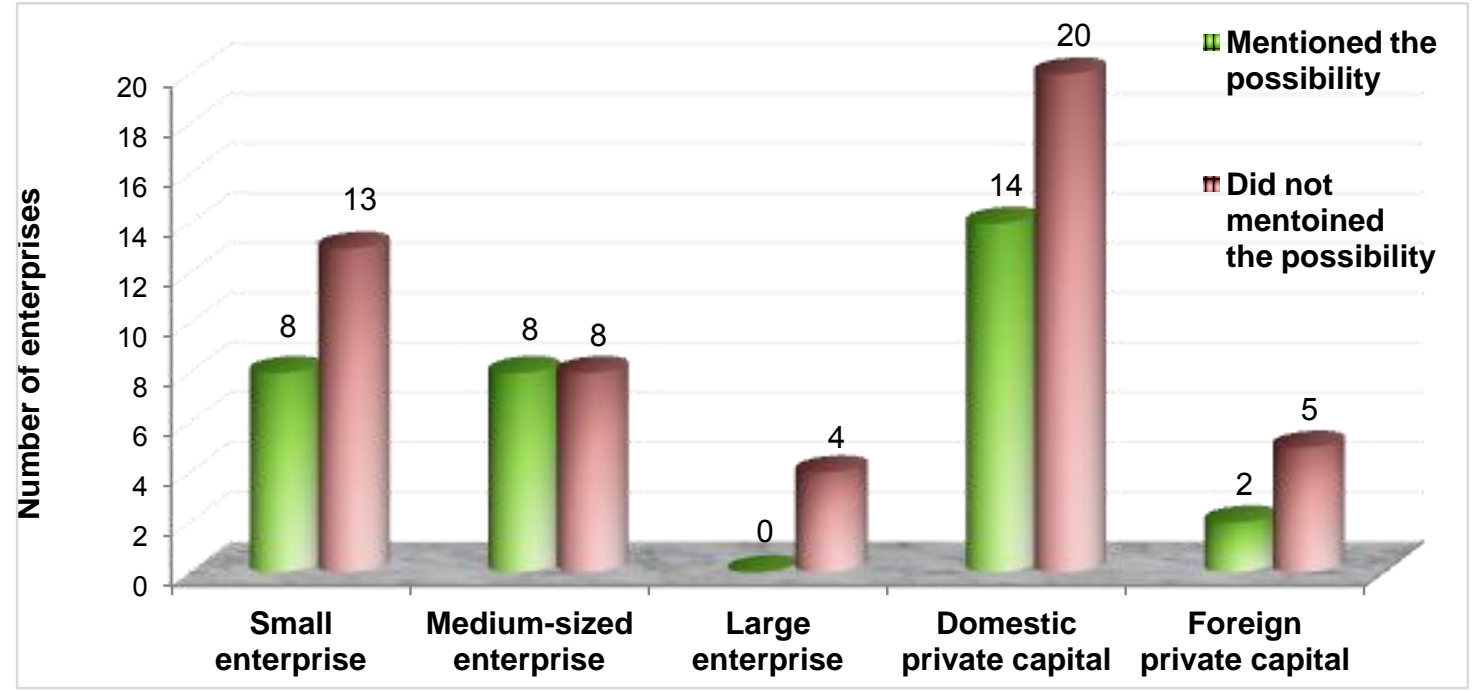

Figure 6: The use of $\mathrm{ABC}$ methods to control costs - I do not know this tool

Question 2: I know this tool but does not use it.

To answer type - I know this tool, but does not use it, 11 were in favor of the 41 firms, representing $27 \%$ of all enterprises. It's seven businesses (33\%) from the group of small businesses and four from the group of small businesses (25\%). In the case of large enterprises were also rejected this alternative all respondents.

In terms of type of capital, for this type of response, 32\% of enterprises were with Slovak capital. In the case of enterprises with foreign capital, this type of response did not accept one. 


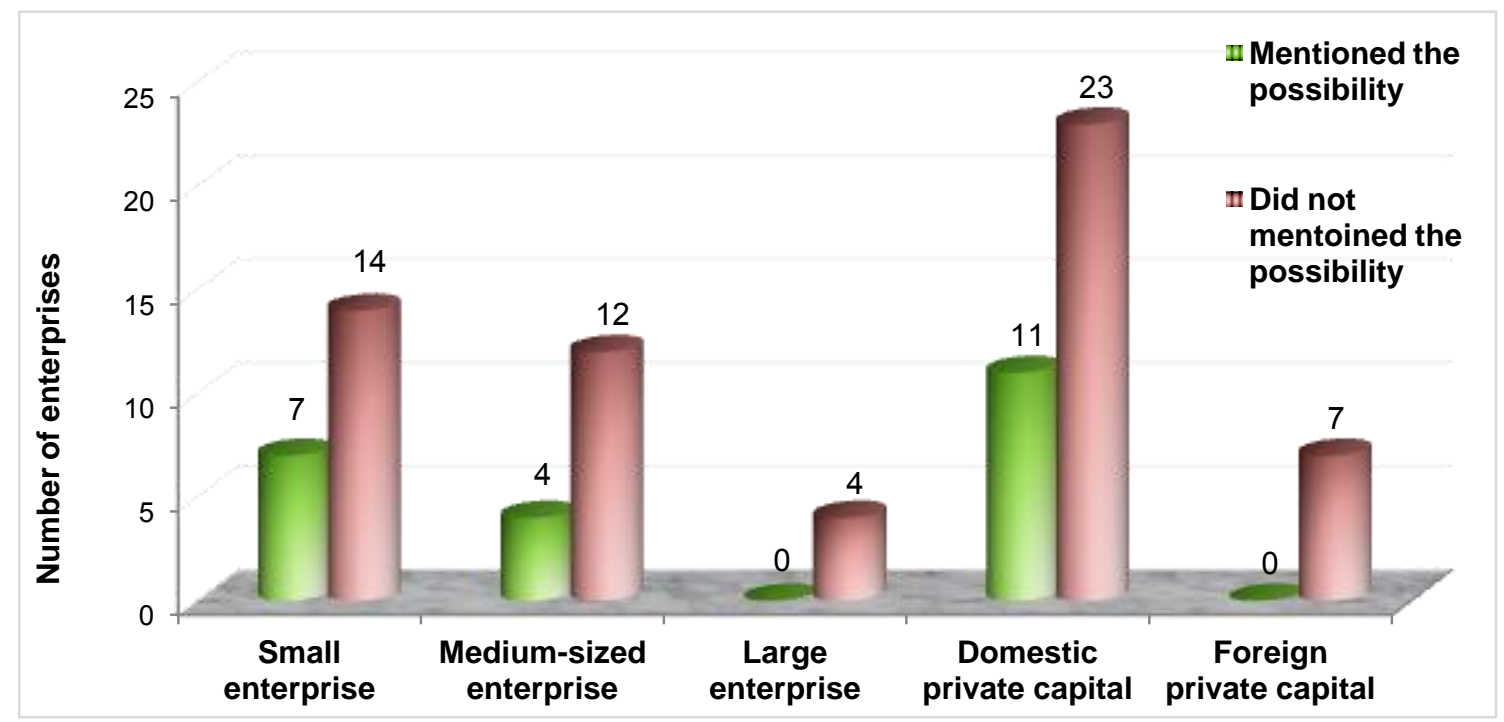

Figure 7: The use of $\mathrm{ABC}$ methods to control costs - I know this tool but do not use it

Activity Based Costing Method identifies areas where it is necessary to reform business processes. Improving information on the cost of the product leads to an improved approach estimating production costs, which are used for determining the final price of the product, budget and plan for the next period. Enterprise thanks to ABC can focus on profitable products or services profitable. Enterprise also gains a competitive advantage in terms of cost and technology and may also focus on the highly profitable clients. ABC method provides more precise information on the identification of the cost of unused capacity and it is thus possible to separately account for such costs. Introduction of the ABC system is obviously associated with upfront costs. Preparing for the introduction, the difficulty survey data to identify activities and the introduction itself is quite time-consuming and thus is therefore costly. For businesses using a system based on volume may be the introduction of the ABC system is very expensive. In some cases it is also necessary to change or at least to optimize the internal information system and it is also necessary for staff training.

$\mathrm{ABC}$ costing is a versatile management tool that not only serves the purpose of cost calculation, but is a tool to enable effective cost reduction. On the other hand, the use of ABC costing redeemed larger amounts of volume and structure of the processed data. In its application is therefore necessary to consider carefully all the benefits and costs associated with its implementation so that the effects it brings, help enterprise to improve performance without unnecessary costs. These are probably the factors that affect the application of this method in construction enterprises. Research indicates that the application of this method in practice is not wide ranged, which is probably related both with the lack of information on this method and with the demands of its application and uses of the practice. 


\section{Conclusion}

Key to the successful performance of the enterprise is undoubtedly the effective cost management. Over the last decade, while significantly increasing the proportion of overhead costs to total costs, the importance of consistent cost management is growing continuously.

Traditional enterprise cost calculation systems in many cases are unable to respond to the needs of the current management. These systems were created in the early 20th century, when the business environment was dominated by heavy industry. Traditional cost systems were previously able to quantify the costs very accurately. Given that the current business conditions, it is necessary to have information on the cost of corporate performance and the shift from traditional to modern calculation methods that allow assignment of costs according to actual performance of their causes, activities. Performed own research came up with following partial findings.

\section{Cost management and monitoring of the effectiveness of processes}

It is a very important business tool - for small, medium and large enterprises as well as enterprises with domestic or foreign capital.

\section{Use of methods of cost management}

Cost controlling use of 15 companies from a total of 41, or $36.5 \%$. Statistical testing confirmed a significant relationship between firm size and the use of cost controlling (F-ratio $=2.775701$, pvalue $=0.039414)$. Process oriented methods of cost management are known in general, but effective using and implementation of these methods in construction enterprises is slow.

\section{The use of cost information}

They are very often used in managerial decision making use of cost information to management decisions depending on the size of business and type of private capital.

\section{Acknowledgements}

The paper presents partial result of project VEGA no. 1/0677/14 „Research of construction efficiency improvement through MMC Technologies“.

\section{References}

[1] Prange, H., Leimboke, E., Klaus, R. (2003). Kalkulácie cien stavebných prác. Best Publishing, Bratislava 2003.

[2] Tažiková, A, Kozlovská, M. (2013). Effect of the construction cost calculations to the sustainable development of buildings. In Visnik Nacional'nogo universitetu L'vivska politechnika : Teorija i praktika budivnictva. No. 756 (2013), 298-303.

[3] Karlőf, B., Őstblom, S. (1995). Benchmarking, jak napodobit úspěšné. Victoria Publishing, Praha, 1995.

[4] Král, B. a kol. (2002). Manažerské účetnictví. Praha: Management Press.

[5] Mesároš, F., Mesároš, P. (2009). Controlling nákladov na stavebné procesy. Košice : VÚSI.

[6] Mesároš, F. (2006). Budovanie systému riadenia nákladov na stavebné procesy s využitím controllingu. In Ekonomika a manažment podniku, 4(1), 31 - 46. 
[7] Mesároš, F., Čarnický, Š. (2003). Plánovanie a sledovanie nákladov realizácie projektu výstavby. In Acta Oeconomica Cassoviensia No7, 251-262.

[8] Nesterak, J. (2001). System informacyjny w procesie controllingu. In Zarzadzanie wartoácia przedsiebiorstwa we vvarunkach globalizacji (wybrane zagadnienia), Szczeciň : Práca zbiorovva pod redakcija naukowa. Urbaňczyka. 